\title{
The Isolation and Occurrence of Hyalochlorella marina
}

\author{
By R. O. POYTON \\ Microbiology Group and Department of Botany, University of California, \\ Berkeley, California 94720, U.S.A.
}

(Accepted for publication 22 April 1970)

\begin{abstract}
SUMMARY
Three out of five methods currently employed in the isolation of lower marine fungi have been effective in the isolation of Hyalochlorella marina from the marine environment. Isolation attempts from locations on the Atlantic, Pacific and Gulf of Mexico Coasts (U.S.A.) indicate that $H$. marina is ubiquitous, occurring in nature either attached to algal filaments or freefloating. Its incidence in the eulittoral and intertidal zones is highest between I4 and $20^{\circ}$. There is no correlation between incidence and the salinities commonly encountered in sea water and numerous attempts at isolation from fresh water have been unsuccessful. It is preferentially attached to algal filaments but exhibits no specificity with regard to particular algae.
\end{abstract}

\section{INTRODUCTION}

Many methods have been developed for isolating unicellular algae into pure culture (Pringsheim, I946; Lewin, I959). Colourless counterparts are usually isolated by taking advantage of their chemoheterotrophic mode of nutrition. Often, however, the isolation of these forms has been fortuitous resulting from their appearance in crude cultures of their green counterparts or on agar media designed for the isolation of yeasts and other fungi (Phaff, Yoneyama \& Do Carmo-Souza, 1964).

Initially the new colourless alga, Hyalochlorella (Poyton, I970), appeared as a contaminant on an agar medium designed for the isolation of lower marine fungi. In isolation attempts, it has often been accompanied by fungi and a large number of undescribed colourless coccoid eucaryotic protists (R. O. Poyton, unpublished) which because of their chemoheterotrophic mode of nutrition and resistance to antibiotics are able to grow on initial isolation plates.

The purpose of this work has been to improve and develop methods which would increase the recovery of Hyalochlorella relative to these other organisms in initial isolation media, and to use these methods in determining its distribution and occurrence in the marine environment.

\section{METHODS}

Five methods were used for the initial isolation of Hyalochlorella. In the first (I), filamentous algae from intertidal and eulittoral zones were collected, sealed in sterile plastic bags (Whirl-Pak; Nasco, Inc., Fort Atkinson, Wisconsin), refrigerated, later cut into fine pieces (I to $2 \mathrm{~cm}$. in length) and after blotting off excess water, placed on the surface of the isolation medium (Vishniac, 1956; Fuller, Fowles \& McLaughlin, I964). The isolation medium contained 370 units streptomycin sulfate $/ \mathrm{ml}$. and 825 
units penicillin ' $G$ ' sodium $/ \mathrm{ml}$. Pieces of algal filaments were sometimes embedded in an overlayer of dilute agar ( $0.7 \%$ ) on the isolation medium (method IA).

In the second method (II), sea water was centrifuged in a two-channel Sorvall KSB 'Szent-Gyorgyi \& Blum' continuous flow system on a Sorvall RC2-B centrifuge (Fuller \& Poyton, I964). Following centrifugation, O.I ml. of the concentrate was plated onto the isolation medium. After filtration through sterile Whatman no. I filter paper to remove large mud particles and debris, this method was used to concentrate suspensions of marine muds.

In the third method (III), sea water and marine mud suspensions (after prefiltration as above) were filtered through sterile nucleopore membrane filters (General Electric, Pleasanton, California) with a pore size of I $\mu \mathrm{m}$. (modification of Miller, I967). The filters were incubated on the surface of the isolation medium. Hyalochlorella colonies were easily visible through the transparent nucleopore membrane.

Two additional methods were unsuccessful in isolating any organisms. The first involved seeding a quantity of sea water with pollen grains (Pinus sp.) and observing after 4,7 and ro day intervals for attached Hyalochlorella filaments (Gaertner, I968). The second method involved immersing microscope slides (sometimes coated with $2 \%$ agar isolation medium) to various depths in the marine environment and observing growth microscopically at various time intervals.

Petri plates for initial isolation procedures were incubated in diffuse light at room temperature $\left(23\right.$ to $25^{\circ}$ ) under aerobic conditions. Plates made from marine mud suspensions were incubated both aerobically and anaerobically under an atmosphere of $6 \% \mathrm{CO}_{2}$ and $94 \% \mathrm{H}_{2}$ (Poyton, 1970 ). Once the isolates were freed from bacterial and mould contamination by single colony transfer, they were placed on the isolation medium without antibiotics. Clones of each isolate were established from single filaments and were maintained as previously described (Poyton, 1970).

Hyalochlorella marina strains 66-5B, 66-6 A, 66-8 A, 68-30 A and 68-3I A were used in studies of the effects of antibiotics on viability and the recovery from continuous flow centrifugation. The origins of these strains are listed elsewhere (Poyton, 1970). Viability was determined by colony counts on the surface of a GDY agar plate after incubation at $20^{\circ}$ (Poyton, 1970). Dilutions were made in sea water with a salinity adjusted to $33 \%$. Salinity was determined by conductivity measurements with a Beckman $\mathrm{RB}_{3}$ Solu Bridge.

\section{RESULTS}

The first three isolation methods provided an array of colourless eucaryotic protists: yeasts, chytridaceous phycomycetes, monocentric phycomycetes of the genera Thraustochytrium and Schizochytrium, Labyrinthula, numerous amoeboid protozoa and Hyalochlorella. Mould, bacterial and diatom growth was minimal. Pollen baiting, a classical isolation technique for aquatic phycomycetes (Sparrow, 1960), and an immersion slide technique commonly used in isolating yeasts from marine waters failed to yield Hyalochlorella.

Hyalochlorella marina was isolated from different inocula and locations (Table I). Temperatures were provided by the U.S. Coast and Geodetic Survey (1960, 1967) and were within $2^{\circ}$ of those readings taken $\mathrm{I} f \mathrm{ft}$ below the water surface at the time of isolation. The incidence was highest in waters between 14 and $21^{\circ}$; no organisms were isolated at water temperatures below $3^{\circ}$ or above $30^{\circ}$. H. marina was isolated from 
Table I. Incidence of Hyalochlorella marina in inocula from a variety of locations

Location Date

Friday Harbor, July 1964

San Juan Island,

Washington

$\begin{array}{ll}\text { Newport, Rhode } & \text { August I964 } \\ \text { Island } & \text { June 1965 } \\ & \text { July 1965 }\end{array}$

August 1965

September 1965

December 1965

January 1966

Wood's Hole, June 1966

Massachusetts

July 1966

August 1966

Galveston, Texas August 1967

March 1968

Berkeley, February I968

San Francisco Bay,

California

\section{May 1968}

June 1968

July $\mathbf{I} 968$

September 1968

Bolinas,

California

July $\mathbf{9} 968$

Bolinas Lagoo

Bolinas,

California

Moss Beach,

California

Presidio Beach,

May 1968

June 1968

September 1968

June 1969
Source of inoculum

Ceramium sp., Polysiphonia sp.

Plankton tow

Sea water $(40 \times)$

Ceramium sp., Polysiphonia sp.

Ceramium sp., Chcrda filum,

Zostera marina

Ceramium sp., Chorda filum, Cladophora sp., Polysiphonia sp.

Dasya pedicellata, Ceramium sp., Chorda filum, Polysiphonia sp.

Ceramium sp., Cladophora sp.,

Enteromorpha sp., Polysiphonia sp.

Ceramium sp., Polysiphonia sp.

Ceramium sp., Chorda filum,

Cladophora sp.

Ceramium sp., Chorda filum,

Cladophora sp., Gelidium sp.,

Polysiphonia harveyi

Ceramium rubrum, Cladophora

gracilis, Dasya pedicellata,

Enteromorpha sp., Polysiphonia sp.

Chorda filum, Enteromorpha sp.,

Polysiphonia denudata

Cladophora sp., Enteromorpha sp.,

Polysiphonia sp.,

Sea water $(1000 \times)$

Sea water $(500 \times)$

Ceramium sp., Polysiphonia sp.

Intertidal mud

Sea water $(1000 \times)$

Ceramium sp., Polysiphonia sp.

Intertidal mud

Sea water $($ I000 $x)$

Ceramium sp., Polysiphonia sp.

Intertidal mud

Sea water $(1000 x)$

Ceramium sp., Polysiphonia sp.

Intertidal mud

Sea water $($ rooo $x)$

Ceramium sp., Polysiphonia sp.

Intertidal mud

Sea water $(\mathrm{I000} \times)$

Ceramium sp., Polysiphonia sp.

Sea water $($ IOOo $\times)$

Intertidal mud

Ceramium sp., Gelidium sp.

Ceramium sp., Cladophora sp., Gelidium sp., Polysiphonia sp.

Ceramium sp., Cladophora sp., Gelidium sp., Polysiphonia

Sea water $(1000 x)$
Isolation

method*

I

I

II

I, IA

I, IA

I, IA

I, IA

I, IA

I, IA

I

I

I

I

II

II

I, IA

II, III

II, III

I, IA

II, III

II, III

I, IA

II, III

II, III

I, IA

II, III

II, III

I, IA

II, III

II, III

I, IA

II

II

I, IA

\} I, IA

I, IA

II
4, 5

$14^{\circ} 0$

4, 5

$15 \circ$

2, 3

I6. 5

Water

temperature

$\sim 2$

$\sim 2$

$\sim 2$

3,4

4, 5

$19^{\circ} 0$

4, 5

20.5

4, 5

I $8 \cdot 5$

6.0

30

$17^{\circ} 0$

$2 I^{\circ} \mathrm{O}$

$2 I \cdot 5$

30.0

17.

$12 \cdot 0$

-

I 8.0

-

20.0

-

$2 \mathrm{I} \cdot \mathrm{O}$

-

$20 \cdot 0$

$-$

I 5.0

-

15.0

$15^{\circ} \mathrm{O}$

California

* The number of the isolation method corresponds to that given in Methods.

+ Incidence is a qualitative indication of the number of colonies present on initial isolation plates. Values are based on a scale of 5 and are normalized to September 1965 collections from which the highest number of isolates were noted on first isolation plates. An incidence of $I=I$ to 5 colonies $/$ plate, $2=6$ to 15 colonies $/$ plate, $3=16$ to 25 colonies/plate, $4=26$ to 35 colonies/plate, $5=36+$ colonies/plate. 
waters of salinities ranging from 25 to $38 \%$. In this range, there was no apparent correlation between incidence and salinity. Hyachlorella could not be isolated from aquatic environments of low salinity. Possibly, the failure to isolate $H$. marina from marine muds was related to its being on obligate aerobe (Poyton, 1970).

Assurance that the isolation methods could be compared quantitatively came from preliminary studies of the effects of antibiotics on viability and from studies of the recovery of viable Hyalochlorella organisms by continuous flow centrifugation. Viable counts of Hyalochlorella marina strains 66-5B, 66-6A, 66-8A, 68-30 A and 68-3 I A grown on the isolation medium supplemented with streptomycin alone ( 148 to 740 units $/ \mathrm{ml}$.) and with both streptomycin ( $370 \mathrm{units} / \mathrm{ml}$.) and penicillin $(825 \mathrm{units} / \mathrm{ml}$.) were identical with viable counts on isolation medium without antibiotics. Streptomycin caused a slight decrease in the growth rate. Viable counts of the five strains of Hyalochlorella were determined before and after continuous flow centrifugation. The average recoveries from three separate determinations of each strain varied between 88.0 and $97.5 \%$; the lowest recoveries varying between 75.0 and $96.1 \%$.

Table 2. Removal of Hyalochlorella organisms from algal substrata by agitation

\begin{tabular}{|c|c|c|c|c|c|}
\hline \multirow[b]{2}{*}{ Algal substrata } & \multirow[b]{2}{*}{ Sample } & \multicolumn{3}{|c|}{ Viable counts (organisms/ml. of alga) } & \multirow[b]{2}{*}{$\begin{array}{l}\text { Percentage of } \\
\text { cells removed } \\
\text { from algal } \\
\text { surface by } \\
\text { agitation } \\
\text { (A) } /(\text { A })+(\text { C) }\end{array}$} \\
\hline & & $\begin{array}{l}\text { Organisms } \\
\text { dislodged } \\
\text { from algal } \\
\text { filaments } \\
\text { by agitation } \\
\text { (A) }\end{array}$ & $\begin{array}{l}\text { Surface-plated } \\
\text { algal } \\
\text { filament } \\
\text { (B) }\end{array}$ & $\begin{array}{l}\text { Embedded } \\
\text { algal } \\
\text { filament } \\
\text { (C) }\end{array}$ & \\
\hline \multirow[t]{6}{*}{ Rhodomela sp. } & I & 0 & o & 0 & - \\
\hline & 2 & 0 & 0 & 0 & - \\
\hline & 3 & 73 & 3 & 3 & 96 \\
\hline & 4 & 0 & 0 & 0 & - \\
\hline & 5 & 33 & 0 & 0 & 100 \\
\hline & 6 & 0 & 0 & 0 & - \\
\hline \multirow[t]{2}{*}{ Endocladia sp. } & $\mathbf{I}$ & 65 & o & 0 & 100 \\
\hline & 2 & 27 & I0 & 0 & 100 \\
\hline \multirow[t]{2}{*}{ Phyllospadix sp.* } & I & 45 & 0 & 0 & 100 \\
\hline & 2 & 120 & 4 & 0 & 100 \\
\hline \multirow[t]{2}{*}{ Gelidium sp. } & I & 200 & $45^{\circ}$ & I 125 & I5 \\
\hline & 2 & 240 & 500 & 725 & 25 \\
\hline \multirow[t]{2}{*}{ Microcladia sp. } & $\mathbf{I}$ & 150 & 7 & 26 & 85 \\
\hline & 2 & 0 & 17 & 14 & 0 \\
\hline \multirow[t]{4}{*}{ Polysiphonia sp. } & I & 78 & 0 & 4 & 95 \\
\hline & 2 & 33 & 0 & 0 & 100 \\
\hline & 3 & 23 & 0 & 7 & 77 \\
\hline & 4 & 68 & 3 & 73 & 48 \\
\hline \multirow[t]{2}{*}{ Cladophora sp. } & I & 78 & I I & 16 & 83 \\
\hline & 2 & 63 & 4 & 10 & 87 \\
\hline
\end{tabular}

The incidence of Hyalochlorella organisms isolated from algal filaments was much higher than from sea water concentrated Iooo-fold. Method IA gave the highest incidence. This might relate to the ability of organisms on all sides of the filament to form colonies when the filament is embedded in agar. The success of methods II and III indicates that Hyalochlorella marina occurs also as a free-floating form. 
Assessment of the degree to which Hyalochlorella was preferentially bound to algal thalli was made by comparing the number of alga-associated filaments/unit volume of alga with the number of free-floating filaments in an equivalent volume of sea water. In the field, pieces of algal thalli were placed into $10 \mathrm{ml}$. of sterile sea water contained in calibrated test-tubes and the volume displaced by the thallus determined to the nearest $0^{\circ} \mathrm{I} \mathrm{ml}$. Each test tube was agitated vigorously for I min. on a Vortex mixer (fastest speed) and the water bathing the filaments was plated on the isolation medium before and after agitation. No viable counts were recorded before agitation. After agitation, pieces of the algal filaments were plated on or embedded in the isolation medium as described in Methods. Sea-water samples were taken less than $2 \mathrm{~m}$. from the point of collection of the thalli, concentrated by method II and viable counts were determined in triplicate. Hyalochlorella colonies were recognized by their spherical highly refractile filaments and lack of rhizoids (Poyton, 1970).

The results reported above were gathered from material collected from Moss Beach, California, during June 1969. Viable counts from sea-water samples gave a concentration of free-floating organisms of $\mathrm{I} \cdot 2 \times \mathrm{IO}^{-1}$ organisms $/ \mathrm{ml}$. With the exception of a few instances in which no counts were registered, the concentration of organisms on the algal surface was 300 to 13,000 times that of free-floating organisms in an equivalent volume of sea water (Table 2). The efficiency with which the vortexing procedure removed Hyalochlorella from the algal surface was variable and depended on the alga (Table 2). Vortex agitation released most or all of the individuals from Rhodomela sp., Endocladia sp., Phyllospadix sp., Microcladia sp. and Cladophora sp.; 50 to $100 \%$ from Polysiphonia sp.; and 15 to $25 \%$ from Gelidium sp. The embedded algal filaments usually gave higher counts/volume of alga than did surface-plated filaments. Plates made from embedded filaments also showed a lower number of yeast and biflagellate phycomycete colonies relative to Hyalochlorella.

The only eucaryotic types which remained associated with the algal thalli after the vortexing procedure were stalked diatoms and Hyalochlorella. The algal filaments were free of moulds and other common fungus contaminants. Hyalochlorella was randomly distributed along each algal thallus, showing no preference for particular regions of the thallus; terminal or basal portions.

\section{DISCUSSION}

Generally, detailed studies of marine eucaryotic protists are restricted to those forms which are either macroscopically obvious or numerically abundant. Knowledge of forms such as Hyalochlorella which fall outside of these two categories is limited by our ability to isolate and grow them. The low incidence of Hyalochlorella relative to other micro-organisms presents a serious obstacle to its isolation by dilution methods. However, its resistance to streptomycin and penicillin and its close association with algal filaments has greatly facilitated its isolation into pure culture. Contamination by other eucaryotic protists is reduced most effectively by washing algal filaments with sterile sea water and embedding them in a thin overlayer of dilute agar isolation medium. The combination of washing, embedding and the use of antibiotics nearly eliminates bacterial, yeast, mould and phycomycete 
contamination. When this procedure is followed, Hyalochlorella can be established in pure culture by single colony transfer directly from isolation plates.

The possibility that Hyalochlorella arises from the bleaching effects of streptomycin on indigenous marine strains of Chlorella is ruled out by the appearance of Hyalochlorella in isolation medium lacking streptomycin altogether, and by the failure of streptomycin concentrations used in the isolation medium to induce colourless variants in marine Chlorella strains.

Despite the fact that Hyalochlorella lacks rhizoids and other obvious means of attachment, its association with algal filaments must be strong enough to resist severance by wave and current action. The type of association involved is at the moment uncertain but might well be attributed to an interaction between Hyalochlorella and either mucilaginous or microfibrillar wall components of the algal substrate. Differences in the wall structure within and between genera of filamentous algae might account for variation in the strength of this interaction. Such an association would not hinder the distribution of an organism, like Hyalochlorella, which undergoes cytokinesis within a mother cell wall, because daughter cells would be liberated as free-floating cells on rupture of the sporangial wall. A similar mode of attachment has been reported for some marine phycomycetes (Vishniac, 1956; Sparrow, 1969). Like Hyalochlorella, these forms are non-selectively associated with a wide range of algal substrata (Vishniac, I956).

The author is indebted to Dr M. S. Fuller for his interest and assistance in securing data reported for isolations made from Friday Harbor and Wood's Hole. This work was supported by a N.A.S.A. grant (NsG(T)-I I 7-2).

\section{REFERENCES}

Fuller, M. S., Fowles, B. E. \& Mclaughlin, D. J. (1964). Isolation and pure culture study of marine phycomycetes. Mycologia 56, 745-756.

Fuller, M. S. \& Poyton, R. O. (1964). A new technique for the isolation of aquatic fungi. Bioscience I4, 45-46.

GAERTNER, A. (I968). Eine Methode des quantitativen Nachweises niederer, mit Pollen köderbarer Pilze im Meerwasse und im Sediment. In Marine Mykologie, pp. 75-89. Edited by A. Gaertner. Bremen: Kommissionsverlag Franz Leuwer.

LEWIN, R. A. (1959). The isolation of algae. Revue Algologique 4, 18I-197.

MilleR, C. E. (1967). Isolation and pure culture of aquatic phycomycetes by membrane filtration. Mycologia 59, 524-527.

Phaff, H. J., Yoneyama, M. \& Do Carmo-Sousa, L. (I964). A one-year, quantitative study of the yeast flora in a single slime flux of Ulmus carpinifolia. Gled. Rivista di Patologia Vegetale, Padova 4, 485-497.

Poyton, R. O. (1970). The characterization of Hyalochlorella marina gen. et sp.nov., a new colourless counterpart of Chlorella. Journal of General Microbiology 62, I7I-I88.

Pringsheim, E. G. (1946). Pure Cultures of Algae, Ist edn. Cambridge University Press.

Sparrow, F, K. (1960). Aquatic Phycomycetes, ist edn. Ann Arbor: University of Michigan Press.

Sparrow, F. K. (I969). Zoosporic marine fungi from the Pacific north-west (U.S.A.). Archiv für Mikrobiologie 66, 129-146.

U.S. COAST AND Geodetic Survey. (1960). Surface Water Temperature and Salinity, Atlantic Coast of North and South America, Ist edn. Washington: U.S. Government Printing Office.

U.S. Coast ANd Geodetic Survey. (1967). Surface Water Temperature and Density, Pacific Coas of North and South America and the Pacific Ocean Islands, 2nd edn. Washington: U.S. Government Printing Office.

Vishniac, H. S. (1956). On the ecology of the lower marine fungi. Biological Bulletin. Marine Biological Laboratory, Wood's Hole, Massachusetts III, 410-414. 